\title{
Traditional first aid in a case of snake bite: more harm than good
}

\author{
Uday Yanamandra, ${ }^{1}$ Sushma Yanamandra ${ }^{2}$
}

${ }^{1}$ Department of Internal Medicine, Armed Forces Medical College, Pune, Maharashtra, India

${ }^{2}$ Department of Medicine, CAIMS, Karimnagar, Andhra Pradesh, India

\section{Correspondence to} Dr Uday Yanamandra, udayj2@gmail.com

\section{DESCRIPTION}

A 22-year-old man bitten by a snake reported to this centre $24 \mathrm{~h}$ after traditional first aid at the village. At presentation, he had no features of systemic envenomation. Local examination of the right lower limb revealed a clear delineation mark secondary to tight bands (tourniquet) (thin black arrows in figures 1 and 2), limb covered with cow dung and use of snake stones. On washing the limb, fang marks (broad red arrow in figure 1) with multiple local incisions/pricks/punctures below the knee in the bitten limb and blisters (figures 2-5) were noticed. Based on the history, he was administered bolus dose of Indian polyvalent antivenin before removing the tourniquet.

The patient developed features of septicaemia, muscle spasms, dysphagia after 7 days of the bite

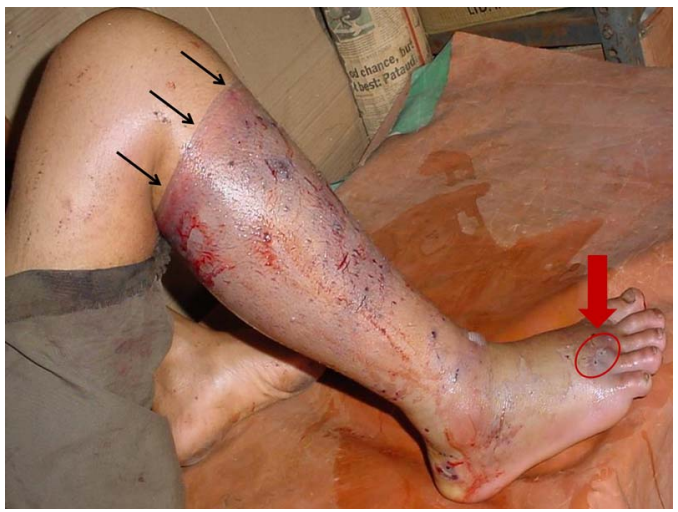

Figure 1 Profile view of local signs in a case of snake bite after traditional first aid. Broad red arrow-fang marks. Thin black arrows-delineation marks at the site of the tourniquet.

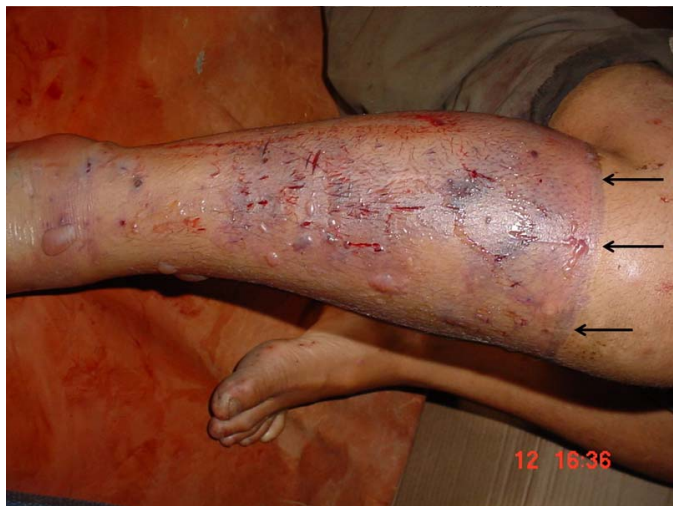

Figure 2 Frontal view of local signs in a case of snake bite after traditional first aid. Thin black arrowsdelineation marks at the site of the tourniquet.

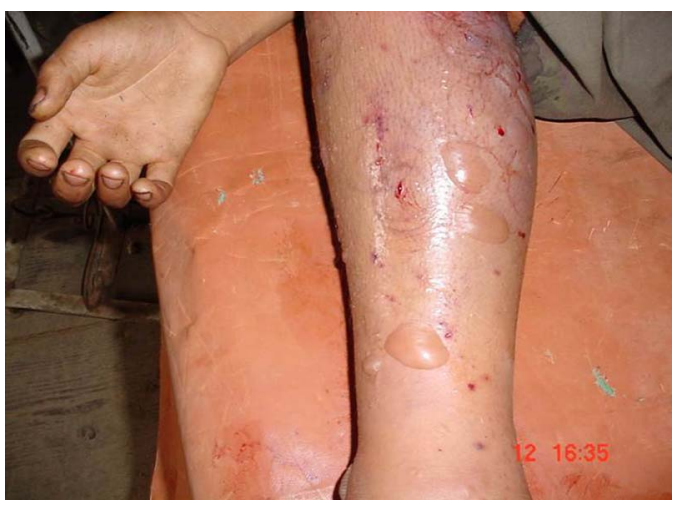

Figure 3 Multiple blisters noticed on the affected limb.

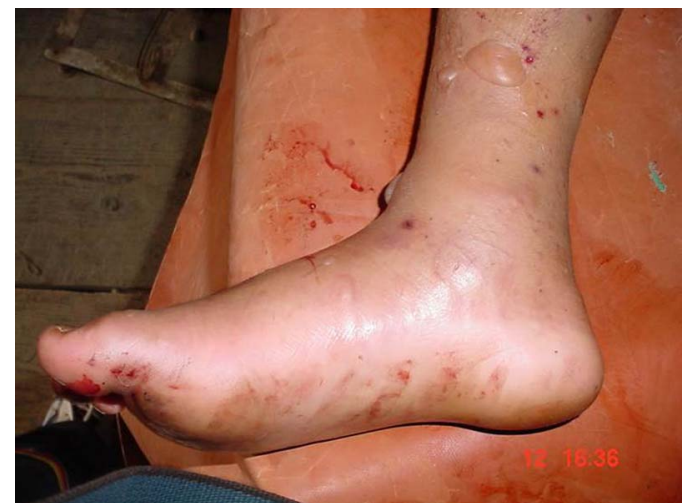

Figure 4 Local oedema of the affected limb.

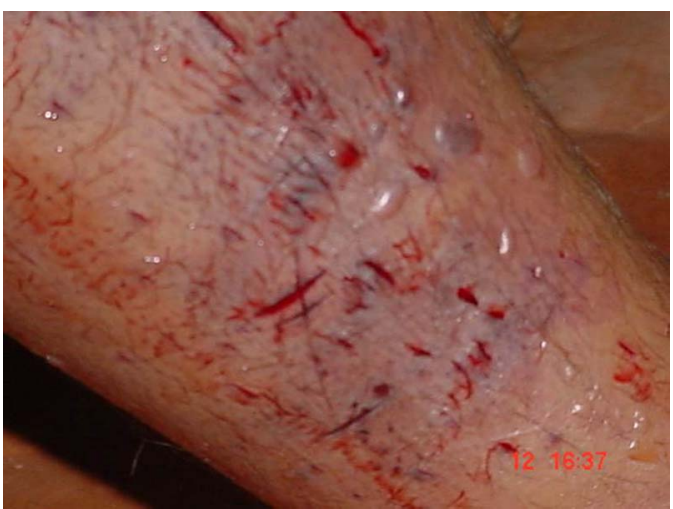

Figure 5 Multiple pricks/ punctures and incision marks of the affected limb.

and later respiratory weakness requiring a prolonged ventilation. Gram stain of blister fluid suggested Clostridium sps. He was managed with antivenin, human antitetanus serum and intravenous diazepam/magnesium/metronidazole.

Similar local signs can be seen in viperine bites. The sequence of clinical events though simulates 
delayed envenomation of cobra bite; important differences are bleeding from the puncture wounds, muscle spasms and no evidence of flaccidity. ${ }^{12}$ Tourniquet, whenever applied on the spot, should be released only in hospital settings and after starting antivenin. ${ }^{2}$ Features in favour of tetanus (mortality of 10-60\%) include incubation period, symptomatology and isolation of

\section{Learning points}

Improper first aid costs more lives than envenomation in snake bites.

- Rural education/awareness campaigns to discourage arterial tourniquet, local incisions/pricks and punctures, suction of the venom and application of cow dung on the site of snake bite is very important.

- Immobilisation of limb and immediate/early transfer to medical facilities should be encouraged. organism in the background of incisions and cow dung application. ${ }^{3}$ This patient had a high possibility of developing gas gangrene as well.

This case highlights detrimental effect of more popular traditional practices.

Contributors YU was involved in managing the case. YS was actively involved in following up the case and preparing the manuscript.

Competing interests None.

Patient consent Obtained.

Provenance and peer review Not commissioned; externally peer reviewed.

\section{REFERENCES}

1 Warrell DA. Bites of venomous snakes. N Engl I Med 2002;347:1804-5; author reply $1804-5$.

2 Watt $\mathrm{G}$, Theakston RDG, Hayes $\mathrm{CG}$, et al. Tourniquet application after cobra bite: delay in the onset of neurotoxicity and the dangers of sudden release. Am J Trop Med Hyg 1988;38:618-22.

3 Marulappa VG, Manjunath R, Mahesh Babu N, et al. A ten year retrospective study on adult tetanus at the Epidemic Disease (ED) Hospital, Mysore in southern India: a review of 512 cases. J Clin Diagn Res 2012;6:1377-80.

Copyright 2014 BMJ Publishing Group. All rights reserved. For permission to reuse any of this content visit http://group.bmj.com/group/rights-licensing/permissions.

BMJ Case Report Fellows may re-use this article for personal use and teaching without any further permission.

Become a Fellow of BMJ Case Reports today and you can:

- Submit as many cases as you like

- Enjoy fast sympathetic peer review and rapid publication of accepted articles

- Access all the published articles

- Re-use any of the published material for personal use and teaching without further permission

For information on Institutional Fellowships contact consortiasales@bmjgroup.com

Visit casereports.bmj.com for more articles like this and to become a Fellow 